\title{
Auxin Prompted Improved Micropropagation Protocol of Picrorhiza kurroa: An Endangered Medicinal Plant
}

\author{
Arif Jan, Phalisteen S*, G.T. Thomas ${ }^{1}$ and A. S. Shawl \\ Division of Biotechnology, Indian Institute of Integrative Medicine, (Formerly, RRL) - \\ CSIR, Sanatnagar, Srinagar, JEK-190005, India
}

Key words: Picrorhiza kurroa, Hardening, Medicinal plant, Propagation

\begin{abstract}
In vitro shoot multiplication from nodal explants of Picrorhiza kurroa Royle ex. Benth. (Kour) was obtained on MS without cytokinin. Addition of NAA in the culture medium favours shoots as well as root formation. Among the various combinations of MS and $\mathrm{B}_{5}$ media, the average number of shoots per explant was (18.3) on MS supplemented with $0.6 \mathrm{mg} / 1$ NAA. Shoot length was maximum (5.8 $\mathrm{cms}$ ) in MS augmented with $0.4 \mathrm{mg} / \mathrm{l}$ NAA. The elongated shoots rooted within 15 - 25 days either on MS alone or supplemented with NAA $(0.4 \mathrm{mg} / \mathrm{l})$, IAA and IBA $(0.1-0.5 \mathrm{mg} / \mathrm{l})$. About $81.5 \%$ of the rooted plantlets survived acclimation and transferred to the greenhouse. All the in vitro derived plants at maturity displayed normal development as that of the mother plants at their maturity.
\end{abstract}

\section{Introduction}

Picrorhiza kurroa Royle ex. Benth. (Kour), a fast depleting high value medicinal plant belongs to Scrophulariaceae and is endemic to alpine Himalayan mountains (3500 - $5000 \mathrm{~m}$ asl). The use of micropropagation techniques for in vitro conservation of this highly endangered medicinal plant has received much attention during the last few decades because of its endangered status and uncontrolled exploitation from natural habitat. Picrorhiza kurroa is the principle source of iridoid glycosides like picrosides-I, II, III and kutkoside (Jia et al. 1999). Other identified active constituents are apocynin, drosin and cucurbitacin (Weinges et al. 1972). Herbal preparation of P. kurroa are used for the treatment of traditional as well as in modern system of medicine as a purgative, brain tonic, stomachic, dyspepsia and antiallergic (Hussain 1984). It is also reported to have anticancer activity (Joy et al. 2000) and extracts can be used as selective enhancers of neuron growth (Li et al. 2000 and Li et al. 2002). Picrorhiza kurroa extracts can also be of therapeutic value in treating viral hepatitis (Mehrotra et al. 1990).

*Author for correspondence: <bioshakir@gmail.com>. ${ }^{1}$ College of Biotechnology, AAI. (D.U.), Allahabad- 211007- India. 
The poor cultivation coupled with over exploitation of rhizomes for pharmaceutical use has depleted the species from the natural habitat, thereby widening the gap between demand and supply and thus putting further pressure on the availability of this species (Nayar and Shastry 1990). The gradual decline in the population of this species demands concrete conservation efforts so as to ensure continuous and ample supply by establishing a balanced cycle of harvest and renewal. Such conservation efforts would ensure continuous supply of this valuable material which is in great demand by the pharmaceutical industry. Only a small percentage of such medicinal plants, used in the industry are cultivated. Most of them are collected from the natural habitat, very often in destructive and unsustainable manners which led to loss of such precious germplasm from its natural habitat. Thus keeping the above facts in mind, the present study was undertaken to develop a suitable regeneration protocol for its rapid multiplication and conservation of its genetic diversity.

\section{Materials and Methods}

Mature seeds for germination were procured from IIIM field stations, Yarikah (District, Baramulla) and Bonera (District, Pulwama), surface disinfected with an aqueous solution of mercuric chloride $(1.0 \% ; 3 \mathrm{mins})$ and thoroughly rinsed thrice with sterile distilled water. The sterilized seeds were imbibed in water for soaking for 15 days at $4^{\circ} \mathrm{C}$ and then kept under continuous dark conditions at 25 $\pm 2^{\circ} \mathrm{C}$ on moist absorbent cotton placed in the Petri plates and germination was monitored on regular intervals.

The basal media consists of mineral salts, vitamins, sucrose $(3 \% \mathrm{w} / \mathrm{v})$, myoinositol $(0.1 \%)$. The $\mathrm{pH}$ of the media was adjusted to $5.8 \pm 0.1$ prior to gelling with $0.8 \%(\mathrm{w} / \mathrm{v})$ agar-agar (Glaxo, bacteriological grade) and autoclaved at 1.05 $\mathrm{kg} / \mathrm{cm}^{2}, 121^{\circ} \mathrm{C}$ for $15 \mathrm{~min}$. Cultures were maintained at $25 \pm 2^{\circ} \mathrm{C}$ in $16 / 8 \mathrm{hr}$ light/ dark cycle by fluorescent tubes (Philips $40 \mathrm{w}$ ) and $65-70 \%$ relative humidity. All experiments were conducted at least thrice with 10 replicates each. MS supplemented with different concentrations of NAA ( 0.2 - $1.0 \mathrm{mg} / \mathrm{l}$, IAA (0.1 - 0.5 $\mathrm{mg} / \mathrm{l})$, IBA ( $0.1-0.5 \mathrm{mg} / \mathrm{l}), \mathrm{BAP}(0.1-0.5 \mathrm{mg} / \mathrm{l})$ and 2,4-D (0.1 - $0.5 \mathrm{mg} / \mathrm{l})$ that were tested alone or in combination for shoot proliferation and elongation. Elongated shoots $(1.2 \mathrm{~cm}$ long) were excised from the culture and transferred to MS supplemented with different concentrations of NAA $(0.2,0.4,0.6,0.8$ and 1.0 $\mathrm{mg} / \mathrm{l})$ alone as well as in combination with IAA and IBA $(0.1,0.25$ and $0.5 \mathrm{mg} / \mathrm{l}$ each) within three weeks. All the cultures were incubated at $25 \pm 2^{\circ} \mathrm{C}$ under $16 \mathrm{hr}$ photoperiod with cool white fluorescent lamps. After three weeks, the percentage of rooting and the number of roots per shoot was assessed. The rooting response of shoots was maximum (92\%) in MS fortified with NAA (0.4 $\mathrm{mg} / \mathrm{l})$. Similar results were reported for many species when NAA was used and 
proved the best among the auxins tested alone or in combination. Rooted micropropagules were thoroughly washed to remove the adhering gel and planted in earthen pots containing a mixture of soil, sand and vermiculite $(1: 1$ : $1: \mathrm{w} / \mathrm{v}$ ) and kept in the greenhouse for acclimation for four weeks. The plants were watered at two-day intervals mixed with one fourth strength of MS inorganic solution twice a week before transfer to open field. The survival rate was recorded one month after transfer to pots. Each treatment consisted of 10 replicates. The data were analyzed statistically using ANOVA and LSD values were calculated at $\mathrm{p}=0.05$ for comparing means of the treatments (Gomez and Gomez 1984).

\section{Results and Discussion}

An in vitro regeneration method has been developed for mass propagation of Picrorhiza kurroa, an endangered and highly valued medicinal plant without using cytokinin. Single medium combination favours best shoot as well as root formation. The highest seed germination rate was obtained when seeds were given cold treatment at $4^{\circ} \mathrm{C}$ for ten days. Among the various strengths of MS and B 5 media (Gamborg et al. 1968), MS supplemented with $0.6 \mathrm{mg} / \mathrm{l}$ NAA showed the highest percentage of direct organogenesis. Maximum nodes per shoot were obtained in media containing lower percentage of sucrose and myo-inositol while shoot length was maximum $(5.8 \mathrm{cms})$ in MS fortified with NAA $(0.4 \mathrm{mg} / \mathrm{l})$. The rooting was optimized using MS supplemented with 0.2 - $1.0 \mathrm{mg} / \mathrm{l}$ NAA. Indirect and direct adventitious shoot regeneration, multiplication as well as their elongation was evaluated on MS with various concentrations of NAA (0.2, $0.4,0.6,0.8$ and $1.0 \mathrm{mg} / \mathrm{l}$ ) alone or in combination with IAA and IBA (Table 1) within three weeks of culture. Earlier, Upadhayay et al. (1989) reported in vitro propagation by using BAP, but in the present study cytokinin has not been proven much effective compared to auxins. These variations in the response of $P$. kurroa could be due to ecotypic differences (Mohapatra and Gressholf 1982). The average number of shoots $18.4 \pm 1.10$ per explant for indirect organogenesis was observed on $0.2 \mathrm{mg} / \mathrm{l} \mathrm{NAA}$ with $80 \%$ response and $18.3 \pm 0.57$ per explant for direct organogenesis was observed on $0.6 \mathrm{mg} / \mathrm{l}$ NAA (Table 1) with $95 \%$ response. These results are very much in conformity with the observations of Qadri et al. (2005), Ahuja et al. (2002) and Zarate et al. (1997). Callus regeneration was observed at the basal cut end of each explant (Fig. 2), which is in agreement with Toth et al. (2000) in Atropha belladonna. The combining effect of IAA and IBA with NAA on nodal segments also promoted direct and indirect shoot multiplication and elongation. However, for indirect regeneration average number of shoots $4.2 \pm 0.64$ per explant was observed on NAA $(0.2 \mathrm{mg} / \mathrm{l})+$ IAA $(0.1 \mathrm{mg} / \mathrm{l})$ with $14 \%$ response (Table 1$)$ and for direct regeneration the number 
was $5.6 \pm 1.26$ per explant on NAA $(0.6 \mathrm{mg} / \mathrm{l})+$ IBA $(0.5 \mathrm{mg} / \mathrm{l})$ with $11 \%$ response. Such findings are strongly supported by those of Ahuja et al. (2002).

Table 1. Effect of NAA alone or in combination with IAA and IBA on direct shoot proliferation and multiplication.

\begin{tabular}{|c|c|c|c|c|}
\hline $\begin{array}{l}\text { Media combinations } \\
(\mathrm{mg} / \mathrm{l})\end{array}$ & $\begin{array}{l}\% \\
\text { response }\end{array}$ & $\begin{array}{c}\text { Av. No. of } \\
\text { shoots/explant }\end{array}$ & $\begin{array}{l}\text { Callus } \\
(\%)\end{array}$ & $\begin{array}{l}\text { Shoot length } \\
(\mathrm{cm})\end{array}$ \\
\hline MS (control) & 10 & $3.3^{\mathrm{e}} \pm 0.76$ & 2 & $1.1^{\mathrm{c}} \pm 0.44$ \\
\hline MS + NAA (0.2) & 60 & $10.4^{\mathrm{cd}} \pm 1.10$ & 30 & $3.2^{b} \pm 0.72$ \\
\hline MS + NAA (0.4) & 76 & $11.8^{\mathrm{bc}} \pm 0.27$ & 25 & $5.8^{\mathrm{a}} \pm 0.89$ \\
\hline MS + NAA (0.6) & 95 & $18.3^{\mathrm{a}} \pm 0.57$ & 40 & $5.6^{a} \pm 0.50$ \\
\hline MS + NAA (0.8) & 80 & $13.2^{\mathrm{b}} \pm 0.67$ & 11 & $5.3^{\mathrm{a}} \pm 0.76$ \\
\hline MS + NAA (1.0) & 73 & $9.4^{\mathrm{d}} \pm 0.95$ & 4 & $3.3^{b} \pm 0.62$ \\
\hline C. $D=0.05$ & & 1.60 & & 1.39 \\
\hline \multicolumn{5}{|c|}{ Combination } \\
\hline MS + NAA (0.6) + IAA (0.1) & 10 & $3.2^{\mathrm{a}} \pm 0.64$ & 2 & $1.4^{\mathrm{a}} \pm 0.34$ \\
\hline $\mathrm{MS}+\mathrm{NAA}(0.6)+\mathrm{IAA}(0.25)$ & 12 & $4.5^{\mathrm{a}} \pm 1.35$ & 3 & $2.0^{\mathrm{a}} \pm 0.42$ \\
\hline MS + NAA (0.6) + IAA(0.5) & 9 & $4.8^{\mathrm{a}} \pm 1.73$ & 2 & $1.3^{a} \pm 0.89$ \\
\hline $\mathrm{MS}+\mathrm{NAA}(0.6)+\operatorname{IBA}(0.1)$ & 11 & $3.3^{a} \pm 0.83$ & 2 & $1.8^{\mathrm{a}} \pm 0.46$ \\
\hline $\mathrm{MS}+\mathrm{NAA}(0.6)+\operatorname{IBA}(0.25)$ & 10 & $4.2^{\mathrm{a}} \pm 0.62$ & 2 & $2.1^{\mathrm{a}} \pm 0.58$ \\
\hline MS + NAA (0.6) + IBA(0.5) & 11 & $5.6^{\mathrm{a}} \pm 1.26$ & 3 & $2.1^{a} \pm 0.59$ \\
\hline C.D. = 005 & & 2.29 & & 1.14 \\
\hline
\end{tabular}

Values with same superscript letters are insignificant at $\mathrm{p}>0.05$.

To our knowledge there are no published reports on multiplication of Picrorhiza from nodal explants without using cytokinin. P. kurroa is propagated through suckers, which are highly prone to viral infections (Dhenuka et al. 1999). In vitro culture provides a powerful tool to eliminate viruses, leading to production of healthy and vigorously growing planting material (Narayanaswamy 1997). Various concentrations of BAP (Table 1) were useful in inducing growth of nodal segments and development of shoot tips. However, the best and rapid growth was observed on MS fortified with NAA $(0.6 \mathrm{mg} / \mathrm{l})$. Further increase in the concentration of NAA had no effect on the number of multiple shoots. In contrast, in other related species, the enhanced level of NAA had stimulating effect on the total number of regenerated plantlets (Slabbert et al. 1993). These results confirmed that some plant species have enough levels of endogenous hormones and do not require high levels of exogenous growth regulators for plant regeneration (Hussey 1982). Emergence of roots occurred within a period of 15 - 25 days. Further incubation of one week led to a very vigorous root growth (Fig. 4). The maximum root growth was recorded on MS 
supplemented with $0.4 \mathrm{mg} / \mathrm{l}$ of NAA (Table 2). During hardening, the plantlets were irrigated with one fourth strength of MS (without sugar and vitamins) for one week.
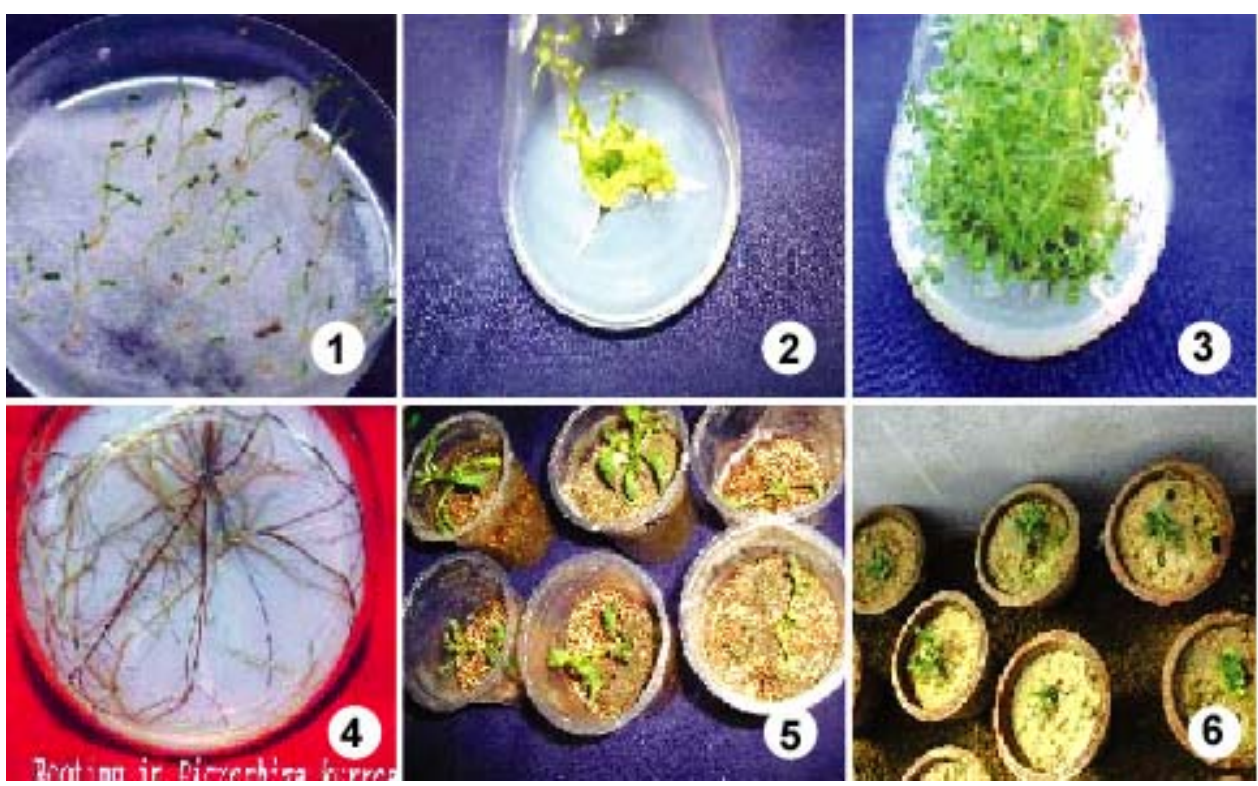

Figs. 1-6: 1. Germination of P. kurroa seeds. 2. Green callus formation. 3. Shoot proliferation in solid MS. 4. Rooting response of shoots. 5. Rooted shoots transferred in polycups. 6. Plantlets transferred to greenhouse for acclimatization.

Although P. kurroa showed spontaneous rooting, the addition of auxins in the rooting medium facilitated higher rooting quality than PGR-free medium in terms of root length and number (Table 1). Direct root initiation and elongation was observed after subculturing of isolated, elongated shoots on to MS supplemented with different concentrations of NAA $(0.2-1.0 \mathrm{mg} / \mathrm{l})$ alone as well as in combination with IAA and IBA $(0.1,0.25$ and $0.5 \mathrm{mg} / \mathrm{l}$ each) within three weeks. The best rooting response of shoots was 92\% (Table 2) on MS supplemented with NAA $(0.4 \mathrm{mg} / \mathrm{l})$. The primary roots became visible after seven days of culturing, however long thin multiple roots were achieved after three weeks. Similar results were reported for many species when NAA was used and the best among the auxins alone or in combination. Each explant developed an average of $17.2 \pm 0.53$ roots with root and shoot length of $11.3 \pm 0.45$ and $20.5 \pm 0.57$, respectively on MS added with $0.4 \mathrm{mg} / \mathrm{l} \mathrm{NAA}$ with an average response of $92 \%$ (Table 2). The complete plantlets, thus formed were hardened in earthen pots (Fig. 5) containing sterile soil, sand and vermiculite (1:1:1) where $81.5 \%$ plants survived successfully (Fig. 6). 
Table 2. Effect of NAA alone or in combination with IAA and IBA on root proliferation and multiplication.

\begin{tabular}{|c|c|c|c|c|c|c|}
\hline $\begin{array}{l}\text { Media combinations } \\
(\mathrm{mg} / \mathrm{l})\end{array}$ & $\begin{array}{c}\text { Response } \\
(\%)\end{array}$ & $\begin{array}{l}\text { Days to } \\
\text { root } \\
\text { induction }\end{array}$ & $\begin{array}{l}\text { No. of } \\
\text { roots / } \\
\text { explant }\end{array}$ & $\begin{array}{l}\text { Root length } \\
\qquad(\mathrm{cm})\end{array}$ & $\begin{array}{l}\text { Shoot length } \\
(\mathrm{cm})\end{array}$ & Callusing \\
\hline MS(control) & - & - & - & - & $3.3 e \pm 0.53$ & ++ \\
\hline MS + NAA (0.2) & 83 & $22 \pm 3$ & $13.5^{\mathrm{b}} \pm 1.2$ & $9.5^{\mathrm{a}} \pm 1.22$ & $16.2^{\mathrm{b}} \pm 0.59$ & + \\
\hline MS + NAA (0.4) & 92 & $18 \pm 2$ & $17.2^{\mathrm{a}} \pm 0.53$ & $11.3^{a} \pm 0.45$ & $20.5^{\mathrm{a}} \pm 0.57$ & + \\
\hline MS + NAA (0.6) & 80 & $13 \pm 2$ & $14.4^{\mathrm{b}} \pm 0.96$ & $4.5^{\mathrm{c}} \pm 0.93$ & $21.4^{\mathrm{a}} \pm 0.57$ & + \\
\hline MS + NAA (0.8) & 30 & $15 \pm 3$ & $12.6^{\mathrm{b}} \pm 1.27$ & $5.3^{c} \pm 0.68$ & $9.2^{c} \pm 0.52$ & ++ \\
\hline MS + NAA (1.0) & 20 & $25 \pm 3$ & $7.2^{\mathrm{c}} \pm 0.55$ & $1.8^{\mathrm{d}} \pm 1.6$ & $4.6^{\mathrm{d}} \pm 0.58$ & + \\
\hline C.D $=0.05$ & & & 1.81 & 2.01 & 1.17 & \\
\hline \multicolumn{7}{|c|}{ Combinations } \\
\hline $\mathrm{MS}+\mathrm{NAA}(0.4)+0.1 \mathrm{IAA}$ & 72 & $23 \pm 3$ & $11.3^{\mathrm{b}} \pm 0.75$ & $7.5^{\mathrm{a}} \pm 1.02$ & $13.3^{\mathrm{b}} \pm 0.57$ & + \\
\hline $\mathrm{MS}+\mathrm{NAA}(0.4)+0.25 \mathrm{IAA}$ & 63 & $23 \pm 4$ & $13.4^{\mathrm{a}} \pm 0.87$ & $2.3^{\mathrm{b}} \pm 0.88$ & $12.5^{\mathrm{b}} \pm 0.67$ & ++ \\
\hline $\mathrm{MS}+\mathrm{NAA}(0.4)+0.5 \mathrm{IAA}$ & 70 & $24 \pm 3$ & $14.1^{\mathrm{a}} \pm 0.53$ & $4.5^{\mathrm{b}} \pm 1.22$ & $12.1^{\mathrm{b}} \pm 0.47$ & + \\
\hline $\mathrm{MS}+\mathrm{NAA}(0.4)+0.1 \mathrm{IBA}$ & 65 & $22 \pm 2$ & $11.4^{\mathrm{b}} \pm 0.78$ & $3.6^{\mathrm{b}} \pm 0.84$ & $14.2^{\mathrm{a}} \pm 0.49$ & + \\
\hline $\mathrm{MS}+\mathrm{NAA}(0.4)+0.25 \mathrm{IBA}$ & 70 & $21 \pm 2$ & $12.5^{\mathrm{ab}} \pm 1.10$ & $8.2 \mathrm{a} \pm 0.49$ & $15.5^{\mathrm{a}} \pm 0.85$ & - \\
\hline $\mathrm{MS}+\mathrm{NAA}(0.4)+0.5 \mathrm{IBA}$ & 70 & $22 \pm 3$ & $13.6^{a} \pm 1.32$ & $3.6^{\mathrm{b}} \pm 0.58$ & $16.2^{\mathrm{a}} \pm 0.49$ & - \\
\hline C.D. $=0.05$ & & & 1.80 & 1.69 & 1.25 & \\
\hline
\end{tabular}

Values with same superscript letters are insignificant at $\mathrm{p}>0.05$.

\section{Acknowledgement}

The authors are highly thankful to the Director, IIIM (CSIR), Sanatnagar, Srinagar for providing the necessary facilities to carry out this research work.

\section{References}

Ahuja A, Sambyal M and Koul S (2002) In vitro propagation and conservation of Atropa acuminate Royle ex Lind- An indigenous threatened medicinal plant. J. Plant Biochem. And Biotech. 11: 121-124.

Dhenuka S, Balakrishna P and Anand A (1999) Indirect organogenesis from the leaf explants of medicinally important plant Curculigo orchioides Gaertn. J. Plant Biochem. and Biotech. 8: 113-115.

Gamborg OL, Miller RA and Ojima K (1968) Nutrition requirements of suspension cultures of Soybean root cells. Expt. Cell Res. 50: 151-158.

Gomez KA and Gomez AA (1984) Statistical Procedures for agricultural research. Wiley, New York.

Hussain A (1984) Conservation of genetic resources of medicinal plants in India, conservation of plant Resources, (Botanical Survey of India): Howrah, India. pp. 110117.

Hussey G (1982) In vitro propagation of monocotyledonous bulbs and corms. Proc. $5^{\text {th }}$ Intl. Cong. Plant Tissue Cell Culture. pp. 677 - 680. 
Jia Q, Hong MF and Minter D (1999) Picroside: a novel iridoid from Picrorhiza kurroa. J. Nat. Prod. 62: 901 - 903.

Joy KL, Rajeshkumar NV, Girija K and Ramadasan K (2000) Effect of Picrorrhiza kurroa extract on transplanted tumours and chemical carcinogenesis in mice. J. Ethnopharmacology 71(1-2): 261-266.

Li J, Wang J, Nawaz Z, Liu J, M, Qin J and Wong J (2000) Both corepressor proteins SMRT and N-CoR exist in large protein complexes containing HDAC3. Embo. J. 19: 4342-50.

Li P, Yu X, Ge K, Melamed J, Roeder RG and Wang Z (2002) Heterogeneous expression and functions of androgen receptor co-factors in primary prostate cancer. American J. Pathol. 161: 1467-74.

Mehrotra R, Rawat S and Kulshreshltha DK (1990) In vitro studies on the effect of certain natural products against hepatitis B virus. Indian J. Med. Res. 92: 133-138.

Mohapatra SS and Greshoff PM (1982) Ecotypic variation of in vitro plantlet from white clover (TrIfolium repens). Plant Cell Reports 1: 189-192.

Narayanswamy S (1997) Plant Cell and Tissue Culture, Tata McGraw-Hill Publishing Co. Ltd., New Delhi, India, pp. 116-118.

Nayar MP and Shastry AR (1990) Red Data Book of Indian Plants. Vol. III (BSI publication: Howrah, India).

Qadri RR, Kamili AN and Shah AM (2005). In vitro multiplication of Atropa acuminates Royle- An important medicinal plant. J. Res. and Development, 5: 129-134.

Slabbert MM, Bruyn MH, Ferriera DI and Pretorius J (1993) Regeneration of bulblets from twin scales of Crinum macowanii in vitro. Plant Cell Tiss. Org. Cult. 33: 133- 141.

Toth ET, Onisei T, Amariei D and Lazurca D (2000) Variability in tissue culture regenerated plants of Atropa belladonna. International Symposium on Plant biotechnology and its contribution to plant development, multiplication and Improvement. ISGS Acta Horticulture 289.

Upadhyay R, Arumugan N and Bhojwani S.S (1989) In vitro propagation of Picrorhiza kurroa Royle ex. Benth-an endangered species of medicinal importance. Phytomorphology 39: 235-242.

Weinges K, Kloss P and Henkels WD (1972) Natural products from medicinal plants XVII, Picroside II, a new 6-vanilloyl catalpol form Picrorhiza kurroa, Liebigs Ann. Chem. 759: 173-182.

Zarate R, Cantos M and Troncoso A (1997) Induction and development of adventitious shoots of Atropa baetica as a means of propagation. Euphytica 94: 361-366. 